\title{
Investigation of Extra-Uterine Tumor Dissemination of Endometrial Cancers with Myometrial Invasion Less Than $50 \%$ According to Histologic Subtypes
}

\author{
(D) Alpaslan Kaban, ${ }^{1}$ (D) Samet Topuz, ${ }^{2}$ (b) Baki Erdem, ${ }^{3}$ () Hamdullah Sözen, ${ }^{2}$ () Yavuz Salihoğlu² \\ 'Department of Obstetrics and Gynecology, Istanbul Training and Research Hospital, Istanbul, Turkey \\ ${ }^{2}$ Department of Obstetrics and Gynecology, Istanbul Faculty of Medicine, Istanbul, Turkey \\ ${ }^{3}$ Department of Obstetrics and Gynecology, Kanuni Sultan Suleyman Training and Research Hospital, Istanbul, Turkey
}

\begin{abstract}
Objectives: This study aims to investigate the rates of extra-uterine metastases of non-endometrioid endometrial tumors limited to the half of the myometrium.

Methods: Patients operated for endometrial cancer between 2005-2015 in two gynecologic oncology centers were screened from clinical archives. The inclusion criteria were serous, clear cell, undifferentiated or carcinosarcoma histologies and less than half myometrial invasion. Each histological type was analyzed for adnexal metastasis, lymph node metastasis (pelvic/paraaortic) and omental metastasis.

Results: A total of 116 patients with the median age of 64 (34-72) were examined. Of the patients, 57 were serous (49.1\%), 29 were clear cell (25.0\%), 27 were carcinosarcoma (23.3\%) and 3 (2.6\%) were undifferentiated histologic type. Adnexal metastasis (over/ tuba) was detected in 15 patients (12.9\%), nodal metastasis in 10 patients ( $8.6 \%)$, and omental metastasis in 15 patients (12.9\%). The rates of adnexal metastases were calculated as $14 \%$ for serous type, $10 \%$ for clear cell type and $11 \%$ for carcinosarcoma. Omental metastasis rates were $11 \%$ for serous type, $17 \%$ for clear cell type and $15 \%$ for carcinosarcoma. The rates of extra-peritoneal nodal metastases were calculated as $12 \%$ for serous type, $7 \%$ for clear cell type and $4 \%$ for carcinosarcoma.

Conclusion: According to the findings obtained in this study, the rates of extra-uterine metastasis are high for serous, clear cell or carcinosarcoma types even in the early period. However, the lymph node metastasis in the carcinosarcoma seems to be lower. A comprehensive staging surgery should be planned for these patients, regardless of the depth of myometrial invasion.

Keywords: Endometrial cancer; extrauterine metastasis; myometrial invasion.

Please cite this article as "Kaban A, Topuz S, Erdem B, Sözen H, Salihoğlu Y. Investigation of Extra-Uterine Tumor Dissemination of Endometrial Cancers with Myometrial Invasion Less Than 50\% According to Histologic Subtypes. Med Bull Sisli Etfal Hosp 2019;53(3):252-255".
\end{abstract}

$E_{n}^{n}$ ndometrial cancer $(\mathrm{EC})$ is the seventh most common malignancy worldwide. ${ }^{[1-3]}$ In Turkey, EC is the fourth cancer type after breast, thyroid and colorectal cancers. ${ }^{[4]}$ Histologically, two subgroups are distinguished as endometrioid and non-endometrioid. Of these, $\sim 10-20 \%$ are non-endometrioid types and have a worse prognosis than endometrioid type. ${ }^{[5-8]}$ These tumors originate from the endometrium, the innermost layer of the uterus, and the tumoral mass progresses locally to the myometrial tissue and serosal layer. According to the 2009 FIGO (The International

Address for correspondence: Alpaslan Kaban, MD. Istanbul Egitim ve Arastirma Hastanesi, Kadin Hastaliklari ve Dogum Klinigi, Istanbul, Turkey Phone: +90 5322609684 E-mail: alpaslankaban@gmail.com

Submitted Date: December 04, 2018 Accepted Date: January 31, 2019 Available Online Date: March 21, 2019

${ }^{\circ}$ Copyright 2019 by The Medical Bulletin of Sisli Etfal Hospital - Available online at www.sislietfaltip.org

OPEN ACCESS This is an open access article under the CC BY-NC license (http://creativecommons.org/licenses/by-nc/4.0/) 
Federation of Gynecology and Obstetrics) staging system, when the tumor progresses to the serosa, the tumor is considered as stage-III. ${ }^{[9]} \mathrm{A}$ tumor that does not exceed one half of the myometrium is accepted as an early period and is staged as IA according to FIGO. In endometrioid type tumors, it is considered that the rate of extra-uterin metastasis is very low in this period and comprehensive staging surgery is not necessary according to the recommendations of many guides, including ESMO-ESGO-ESTRO. ${ }^{[10]}$

The present study aims to investigate the risk of extra-uterine metastasis in non-endometrioid endometrial carcinomas and to discuss the necessity of comprehensive staging surgery in the early period. For this, in the present study, the presence of tumor in the adnex (over/tuba), omentum and lymph nodes (pelvic/paraaortic) was investigated when the tumor was limited to the first half of the myometrium.

\section{Methods}

In this study, we evaluated 116 cases who had undergone staging surgery for endometrium ca between 2005 and 2015 at Gynecological Oncology Departments of two Research and Education Hospitals. Patients with serous, clear cell, undifferentiated and carcinosarcoma histologic types whose myometrial invasion is less than one half were selected. Hysterectomy and bilateral salpingo-oophorectomy plus lymphadenectomy and omentectomy were defined as staging operation. In this study, patients without lymphadenectomy and patients with very few lymph nodes removed (less than 6 lymph nodes) were excluded from this study regardless of the presence of paraaortic lymphadenectomy. Pathologic data were obtained from postoperative pathology reports reported by gynecopathologists in both hospitals. The following findings of patients were recorded: age, histological subtype, adnexal metastasis (fallopian tube/ovary), omental metastasis and lymph node metastases. Adnexal metastasis, omental metastasis and lymph node metastasis rates were calculated for each subtype.

Ethical Committee approval form was obtained from the Ethics Committee of Istanbul University (Date: 9/3/2018 Decision No: 05). All patients signed an informed consent that allowed our center to use their clinical data for scientific trials.

\section{Statistical Analysis}

For statistical analysis, IBM SPSS Statistics Version 22 was used. Chi-square test and Fisher exact test were used for adnexal metastasis and omentum metastasis relation.

\section{Results}

One hundred sixteen patients with a median age of 64 (34-78) were included in this study. Of the patients, 57 were serous (49.1\%), 29 were clear cell $(25.0 \%)$, and 27 were carcinosarcoma (23.3\%). In three patients $(2.6 \%)$, undifferentiated adenocarcinoma was observed (Table 1). Eleven patients (12.8\%) had adnexal (over/tuba) metastasis, 10 (8.6\%) had lymph node metastasis, and 15 (12.8\%) had omental metastases. Fifty-three percent of omentum metastases were macroscopic $(n=8), 47 \%$ and $(n=7)$ were microscopic metastases. Omentum metastasis was most frequently seen in clear cell carcinoma (17\%), followed by carcinosarcoma (15\%) and serous adenocarcinoma (11\%). The rate of nodal metastasis was highest in serous type (12\%), followed by clear cell (7\%) and carcinosarcoma (4\%). Paraaortic nodal metastasis was detected only in one patient. This patient had serous histology. Adnexal metastases were the most common in serous type (14\%), followed by clear cell (10\%) and carcinosarcoma (11\%) (Fig. 1). Patients with adnexal metastasis had a significantly higher percentage of omentum metastases ( $47 \%$ and $8 \%, \mathrm{p}=0.001$ ) (Table 2). When we consider the relationship between omental micrometastasis and adnexal metastasis, we found that the rates of micrometastasis in omentum were higher in patients with adnexal metastasis, but the difference was not significant (\%5 and \%13, $\mathrm{p}=0.223$ ) (Table 3).

Table 1. Outcomes of extra-uterine metastases in 116 patients with non-endometrioid endometrium cancer with a myometrial invasion rate of less than $50 \%$

\begin{tabular}{|c|c|}
\hline Feature & Value \\
\hline Age(year), median & $64(34-78)$ \\
\hline \multicolumn{2}{|l|}{ Histological type, n\% } \\
\hline Serous & $57(49.1)$ \\
\hline Clear-cell & $29(25.0)$ \\
\hline Carcinosarcoma & $27(23.3)$ \\
\hline Undifferantiated & $3(2.6)$ \\
\hline \multicolumn{2}{|c|}{ Locations of extra-uterine metastasis, n \% } \\
\hline Adnexal metastasis & 15 (12.9) \\
\hline Omentalmetastasis & $15(12.9)$ \\
\hline Macroscopic & 8 \\
\hline Microscopic & 7 \\
\hline Lymph node metastasis & $10(8.6)$ \\
\hline \multicolumn{2}{|c|}{ Rates of omental metastases, $\%$} \\
\hline Serous & 11 \\
\hline Clear-cell & 17 \\
\hline Carcinosarcoma & 15 \\
\hline \multicolumn{2}{|l|}{ Rates of nodal metastases, $\%$} \\
\hline Serous & 12 \\
\hline Clear-cell & 7 \\
\hline Carcinosarcoma & 4 \\
\hline \multicolumn{2}{|c|}{ Rates of adnexal metastases, \% } \\
\hline Serous & 14 \\
\hline Clear-cell & 10 \\
\hline Carcinosarcoma & 11 \\
\hline
\end{tabular}




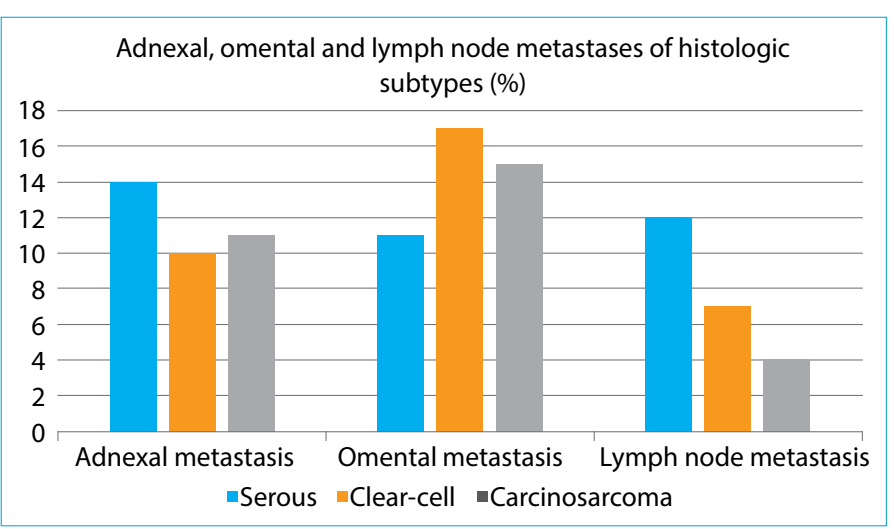

Figure 1. Adnexal, omental, and lymph node metastasis of histological tumor types.

Table 2. Risk of omentum metastasis in patients according to presence of adnexal metastasis

\begin{tabular}{lcccc}
\hline & \multicolumn{2}{c}{ Adnexal metastasis } & & \\
\cline { 2 - 3 } Omental metastasis & No & Yes & Total & p \\
\hline No metastasis, $\mathrm{n}(\%)$ & $93(92)$ & $8(53)$ & 101 & 0.001 \\
Present metastasis, $\mathrm{n}(\%)$ & $8(8)$ & $7(47)$ & 15 & \\
Total & 101 & 15 & 116 & \\
\hline
\end{tabular}

Table 3. Assessment of microscopic omentum metastasis in the presence of adnexal metastasis

\begin{tabular}{|c|c|c|c|c|}
\hline \multirow[t]{2}{*}{ Micrometastasis at omentum } & \multicolumn{2}{|c|}{ Adnexal metastasis } & \multirow[b]{2}{*}{ Total } & \multirow[b]{2}{*}{$\mathbf{p}$} \\
\hline & No & Yes & & \\
\hline No micrometastasis, n (\%) & $96(95)$ & $13(87)$ & 109 & 0.223 \\
\hline Present micrometastasis, n (\%) & $5(5)$ & $2(13)$ & 7 & \\
\hline Total & 101 & 15 & 116 & \\
\hline
\end{tabular}

\section{Discussion}

The present study aimed to discuss whether a comprehensive staging surgery was necessary for early-stage non-endometrioid endometrial cancer patients. We have examined the patients with serous, clear cell and carcinosarcoma histology who did not exceed $50 \%$ of myometrial invasion and evaluated the rates of metastasis to the omentum, adnexa and lymph nodes in these patients. We have combined patients from two gynecological oncology centers to conduct a larger study.

In this study, findings showed that the rates of extra-uterine metastases in serous, clear cell and carcinosarcoma histological subgroups were not low. Omental metastasis rates were found to be $11-17 \%$. Clear cell and carcinosarcoma subtypes had increased risk for omental metastasis. Interestingly, the rates of nodal metastases in these histological types were lower than serous type (Fig. 1). While retroperitoneal metastasis is more common in patients with serous adenocarcinoma, clear cell and carcinosarcoma types might be more prone to omental spread (Fig. 1). In our study, the myometrial invasion was less than one half in all patients, but the overall omental metastasis rate was $12.9 \%$. However, in patients with non-endometrioid histology, there is no consensus on whether omentectomy should be a part of staging surgery. The ESMO-ESGO-ESTRO (European Society for Radiotherapy Oncology and European Society of Gynecological Oncology) group recommends omentectomy for serous histology, but not necessarily required for carcinosarcoma and clear cell adenocarcinoma. ${ }^{[10]}$ The National Comprehensive Cancer Network (NCCN) guideline supports that all of the non-endometrioid types are at high risk and that the omentectomy is part of the staging surgery. ${ }^{[11]}$ Kaban et al.'s ${ }^{[12]}$ study showed that all patients with non-endometrioid type omentectomy were proposed, which seems reasonable that omentectomy is part of the staging surgery in non-endometrioid histologies.

\section{Is Re-Operation Necessary for Staging Surgery in Non-Endometrioid Histology That Has Been Detected Incidentally?}

Inconsistency between the biopsy and the final pathology is possible. ${ }^{[13-15]}$ When incidentally non-endometrioid histology is detected, there are no clear recommendations in the management. Reoperation for staging may be considered in these patients according to the results of this study because the omental metastasis rate was $11-17 \%$ (stage IV) and nodal metastasis rate was 4-12\%. Differently, in a study conducted by Peled et al., ${ }^{[16]}$ the findings indicated that the survival rate was not different in the patients who had omentectomy or not in patients with serous endometrial carcinoma and reoperation was not recommended. However, reoperation may be useful for the detection of the stage and a more appropriate adjuvant treatment plan. In another result of the study, it can be accepted whether the presence of adnexal metastasis as a criterion for reoperation decision for omentectomy if only hysterectomy and salpingo-oophorectomy were performed. The findings in the present study suggest that the presence of adnexal metastasis for the prediction of omentum metastasis was a significant indicator in comparative analysis. In the absence of adnexal metastasis, the rate of omentum metastasis was $8 \%$, while the presence of adnexal metastasis was $47 \%$ $(\mathrm{p}=0.001)$ (Table 2).

In this study, we have evaluated patients with non-endometrioid endometrium carcinoma regarding extra-uterine metastasis. Nonendometrioid histology accounts for $10-15 \%$ of endometrium cancers. ${ }^{[7]}$ The data were collected from two centers over a 10-year period. This was a limitation of this study, so larger studies are needed. Given 
that pathological examinations of preperats have not been reevaluated for this study can be seen as another limitation.

\section{Conclusion}

In conclusion, our findings showed that in non-endometrioid EC, the risk of extra-uterine metastases is not low even in the early stages. If these histological types are detected by endometrial biopsy before surgery or incidentally after surgery, staging surgery, including omentectomy, should be planned.

\section{Disclosures}

Ethics Committee Approval: Ethical Committee approval form was obtained from the Ethics Committee of Istanbul University (Date: 9/3/2018, Decision no: 05).

Peer-review: Externally peer-reviewed.

Conflict of Interest: No conflict of interest.

Authorship contributions: Concept - A.K., S.T., B.E., H.S., Y.S.; Design - A.K., S.T., B.E., H.S., Y.S.; Supervision - A.K., S.T., B.E., H.S., Y.S.; Materials - A.K., S.T., B.E., H.S., Y.S.; Data collection \&/or processing - A.K., S.T., B.E., H.S., Y.S.; Analysis and/or interpretation - A.K., S.T., B.E., H.S., Y.S.; Literature search - A.K., S.T., B.E., H.S., Y.S.; Writing A.K.; Critical review - S.T.

\section{References}

1. Siegel RL, Miller KD, Jemal A. Cancer statistics, 2016. CA Cancer J Clin 2016;66:7-30. [CrossRef]

2. UK CR. Worldwide cancer statistics. Cancer Res UK 2014;2012:2012-5.

3. Siegel R, Naishadham D, Jemal A. Cancer statistics, 2013. CA Cancer J Clin 2013;63:11-30. [CrossRef]

4. Köse MR, Başara BB, Güler C, Yentür GK. Sağlık Bakanlığı İstatistik Yıllığı 2013. Available at: http: // www. sagem.gov.tr. Sağlık Bakanlığı Araştırma Genel Müdürlüğü. Accessed Ankara, 2014.

5. Kosebay D, Beşe T, Ergun E, Demirkıran F, Arvas M, Moin F, et al. Endometrium kanserinde sağkalım ve hastalıksız yaşam süresine etki eden prognostik faktörlerin değerlendirilmesi. Turkiye Klin J
Gynecol Obs 1996;6:259-68.

6. Düzgüner $\mathrm{S}$, Ilgın $\mathrm{H}$, Taşçı T, Düzgüner iN, Turan T, Boran N, et al. Miks tip endometrium kanseri analizi. J Turk Soc Obs Gynecol 2014;11:119-25. [CrossRef]

7. Amant F, Moerman P, Neven P, Timmerman D, Van Limbergen E, Vergote I. Endometrial cancer. Lancet 2005;366:491-505. [CrossRef]

8. Reynaers EA, Ezendam NP, Pijnenborg JM. Comparable outcome between endometrioid and non-endometrioid tumors in patientswith early-stage high-grade endometrial cancer. J Surg Oncol $2015 ; 111: 790-4$. [CrossRef]

9. Lewin SN. Revised FIGO staging system for endometrial cancer. Clin Obstet Gynecol 2011;54:215-8. [CrossRef]

10. Colombo N, Creutzberg C, Amant F, Bosse T, González-Martín A, Ledermann J, et al. ESMO-ESGO-ESTRO Consensus Conference on Endometrial Cancer: Diagnosis, Treatment and Follow-up. Int J Gynecol Cancer 2016;26:2-30. [CrossRef]

11. NCCN. NCCN Clinical Practice Guidelines in Oncology: Uterine Neoplasms. 2015. (https://www.nccn.org/professionals/physician_gls/default.aspx)

12. Kaban A, Topuz S, Erdem B, Sozen H, Numanoğlu C, Salihoğlu Y, Is Omentectomy Necessary for Non-Endometrioid Endometrial Cancer. Gynecol Obstet Invest 2018;83:482-486. [CrossRef]

13. Helpman L, Kupets R, Covens A, Saad RS, Khalifa MA, Ismiil N, Assessment of endometrial sampling as a predictor of final surgical pathology in endometrial cancer. Br J Cancer 2014;110:60915. [CrossRef]

14. Batista TP, Cavalcanti CL, Tejo AA, Bezerra AL. Accuracy of preoperative endometrial sampling diagnosis for predicting the final pathology grading in uterine endometrioid carcinoma. Eur J Surg Oncol 2016;42:1367-71. [CrossRef]

15. Thanachaiviwat A, Thirapakawong C, Leelaphatanadit C, Chuangsuwanich T. J Med Accuracy of preoperative curettage in determining tumor type and grade in endometrial cancer. Assoc Thai 2011;94:766-71.

16. Peled Y, Aviram A, Krissi H, Gershoni A, Sabah G, Levavi H Uterine papillary serous carcinoma pre-operatively diagnosed as endometrioid carcinoma: Is omentectomy necessary? Aust N Z J Obstet Gynaecol 2015;55:498-502. [CrossRef] 